\title{
ПЕРСПЕКТИВИ РОЗВИТКУ ФАРМАЦЕВТИЧНОГО ФАКУЛЬТЕТУ
}

\author{
Л. В. Соколова, Д. Б. Коробко, П. Г. Лихацький \\ ДВНЗ “Тернопільський держсавний медичний університет імені І. Я. Горбачевського \\ МОЗ Украӥни”
}

\section{PROSPECTS OF DEVELOPMENT OF PHARMACEUTICAL FACULTY \\ L. V. Sokolova, D. B. Korobko, P. H. Lyhatskyi \\ SHEI "Ternopil State Medical University by I. Ya. Horbachevsky of MPH of Ukraine”}

\begin{abstract}
У статті висвітлені перспективи розвитку факультету з навчально-методичної, наукової та організаційної роботи і шляхи їх вирішення, які тісно пов'язані із загальною концепцісю розвитку Тернопільського державного медичного університету.
\end{abstract}

The article outlines the perspectives of development of a faculty from educational and methodological, scientific and organizational work and ways their decision that are closely related to general concept of the development of Ternopil State Medical University.

Проблема якості надання освітніх послуг є важливою для всіх вищих навчальних закладів, їх факультетів, як структурних підрозділів, в томучислі й фармацевтичного. Якісна підготовка майбутніх фахівців є запорукою прогресивного розвитку факультету, його конкурентоспроможності на фармацевтичному ринку освітніх послуг.

Підвищення ефективності і конкурентоспроможності вищої фармацевтичної освіти необхідно пов'язати зі стратегічним менеджментом. Такому підходу притаманний зв' язок управлінської діяльності факультету 3 урахуванням вимог керівництва університету, аналізу зовнішніх і внутрішніх можливостей факультету, наявного контингенту студентів, готовності працівників факультету до сучасних нововведень. Стратегічний менеджмент дозволяє визначити цілі факультету і сформувати основні концептуальні питання розвитку факультету.

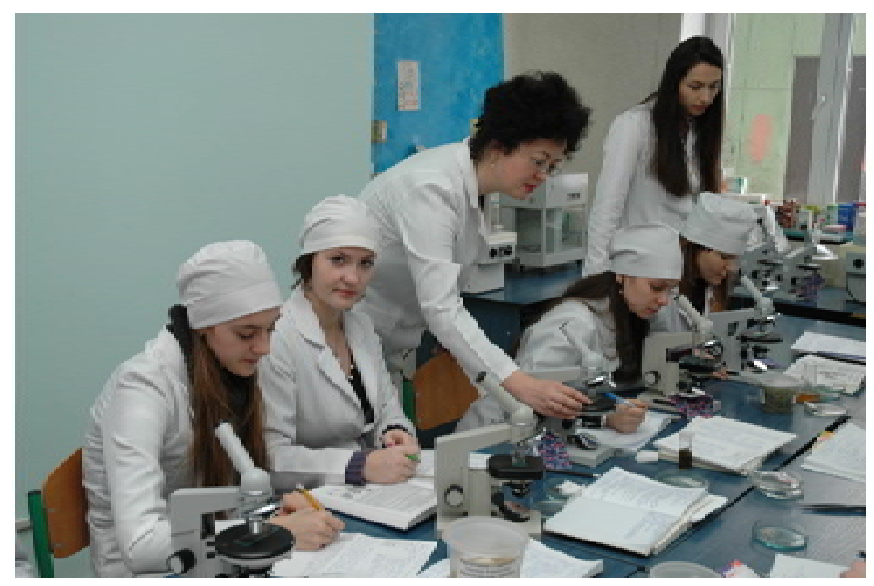

За стратегічну мету розвитку факультету пропонується прийняти: "Підвищення якості підготовки конкурентоздатних фахівців до рівня, що забезпечить їм можливість успішно працювати за фахом, яке базується на інноваційних, грунтовних, систематичних знаннях, які надаються студентам висококваліфікованими викладачами".

Підвищення якості підготовки фахівців у галузі фармації має грунтуватися на прогнозуванні перспектив розвитку фармацевтичної галузі, на вивченні й запровадженні досвіду світових лідерів вищої фармацевтичної освіти та використовуючи кращий власний досвід, в тому числі і організаційної роботи.

Підготовка досвідчених фахівців та формування інтелектуальної еліти суспільства у фармацевтичній галузі має базуватися на грунтовній, систематичній навчально-методичній роботі.

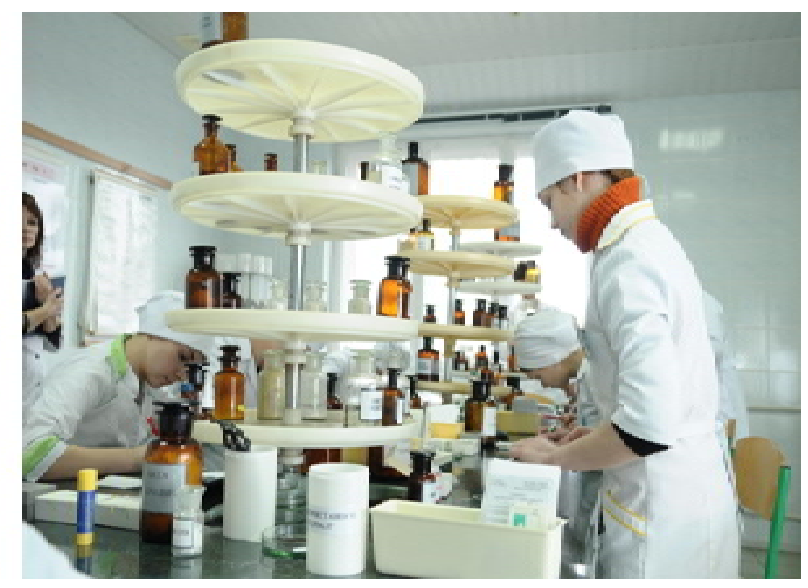

( Л. В. Соколова, Д. Б. Коробко, П. Г. Лихацький 
Пріоритетність науки на фармацевтичному факультеті обумовлена тим, що викладач не тільки зобов’ язаний навчити студентів використовувати свій інте-

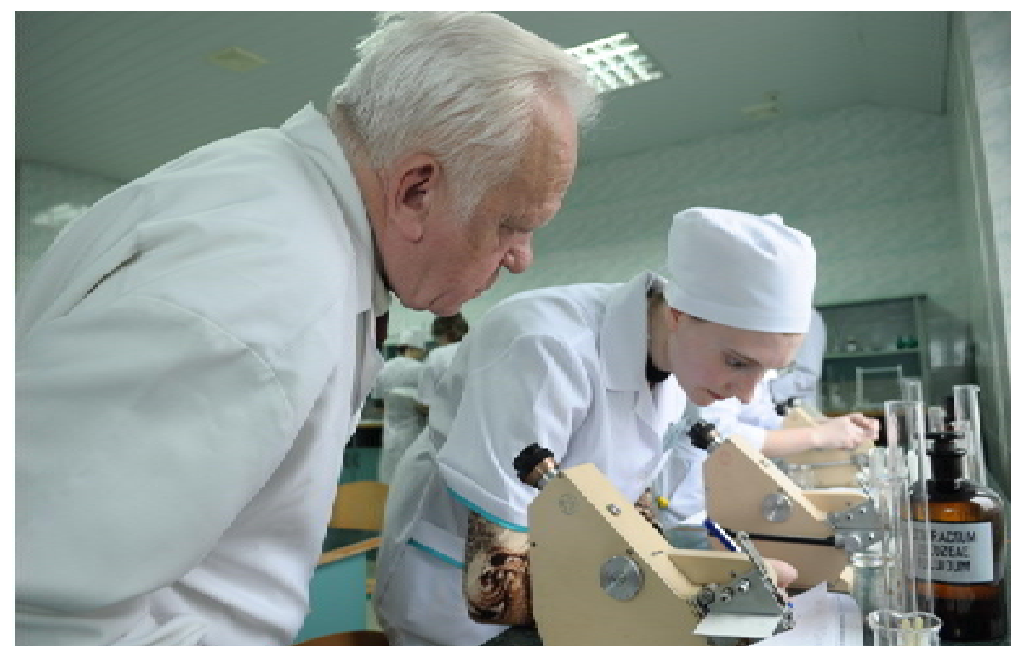

лект для пошуку і засвоєння вже існуючих відповідних знань, а й проявляти творчість і креативність при проведенні наукових досліджень.
Для цього необхідно:

- Активніше залучати студентську молодь до виконання експериментальних досліджень за різними на-

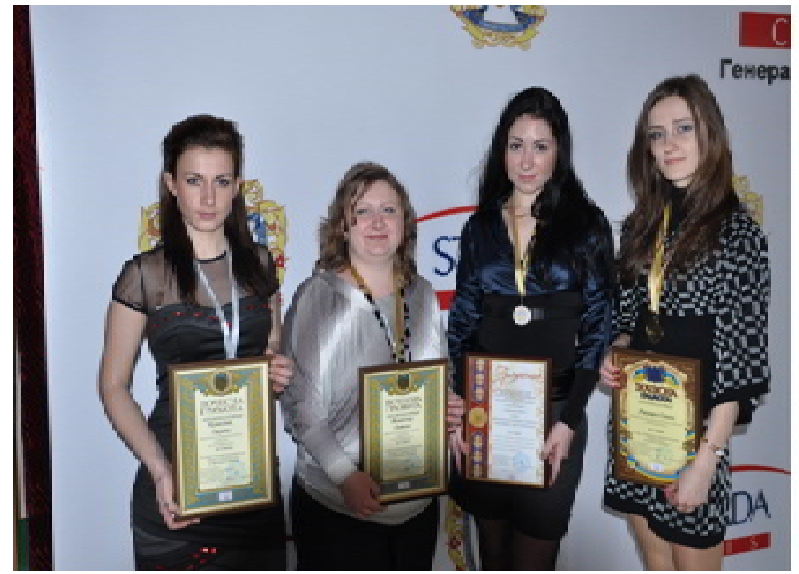

· Результати наукових досліджень активніше впроваджувати в практичну фармацію, науковий та на-

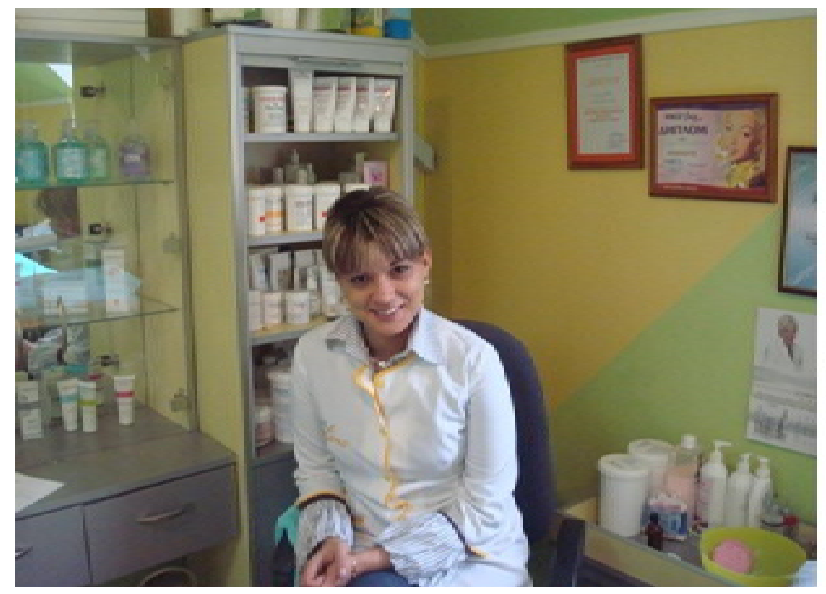

· Для підвищення рівня досліджень використовувати найсучасніші підходи, методи та методики, що прямками фармацевтичної науки та представлення одержаних результатів на наукових форумах, конгреcax, конкурсах всеукраїнського й міжнародного рівнів.
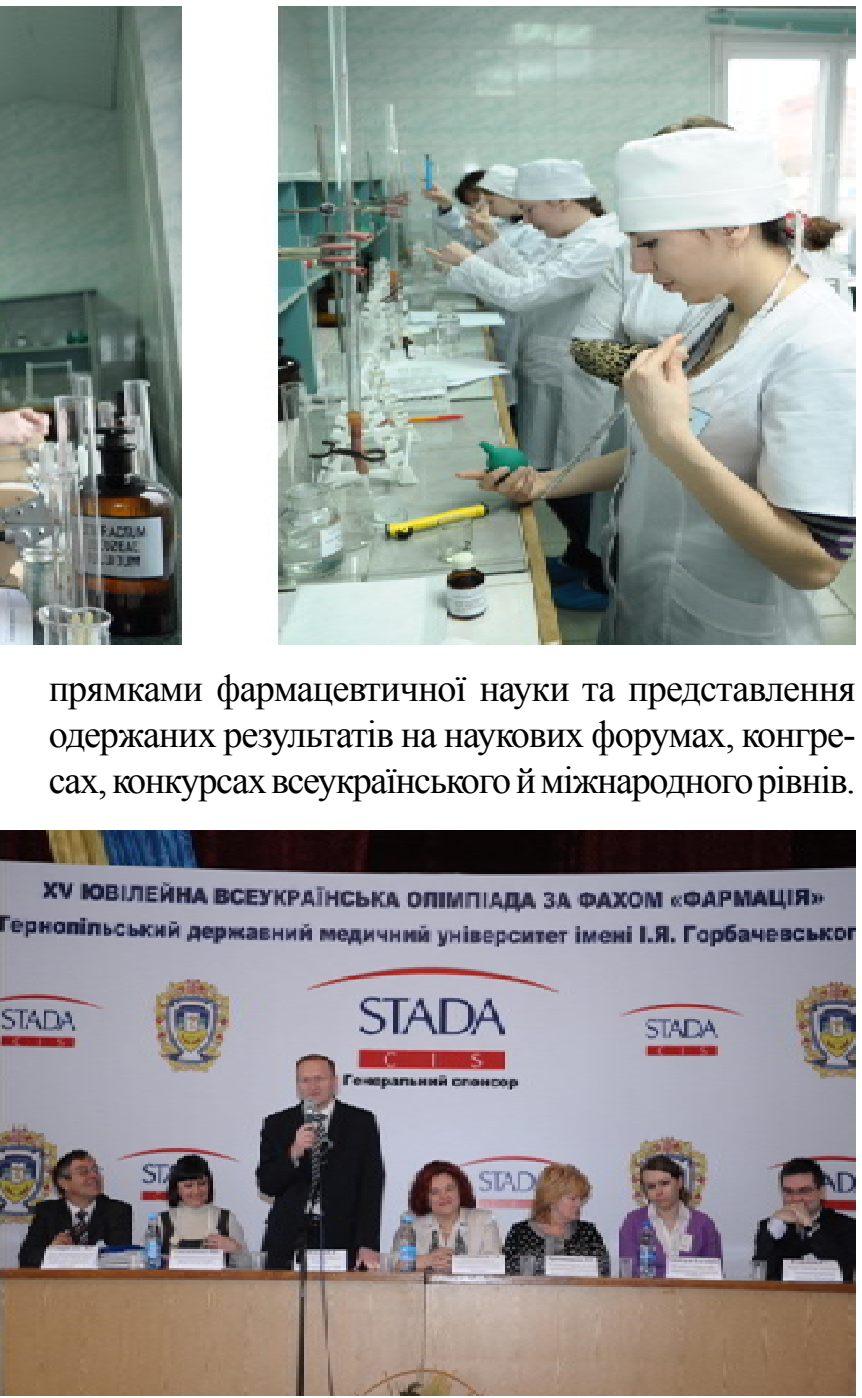

вчально-методичні процеси відповідних кафедр ВНЗ України.

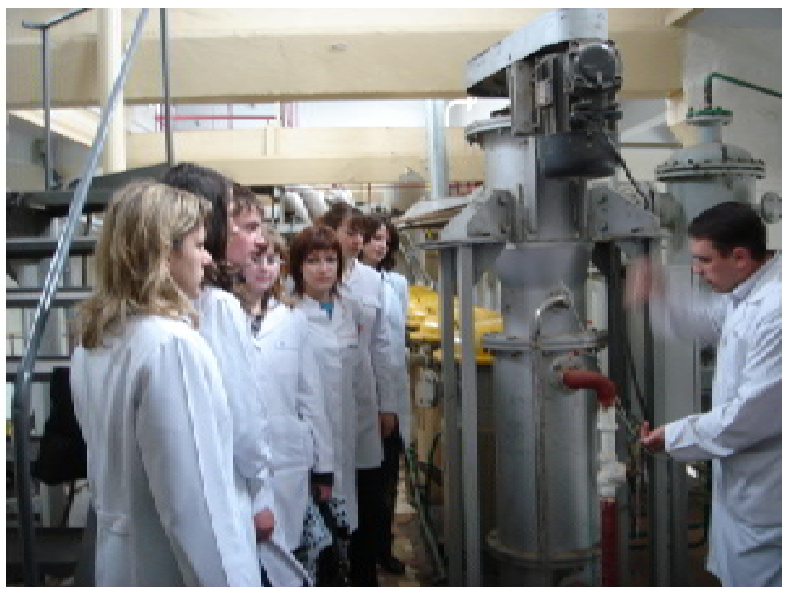

дозволить одержані результати публікувати у виданнях з високим індексом цитування. 
• Наукові здобутки відображати не тільки в деклараційних патентах на корисну модель або інформаційних листах, але й в патентах на винахід, в тому числі й міжнародних, що підтверджують інтелектуальну власність.
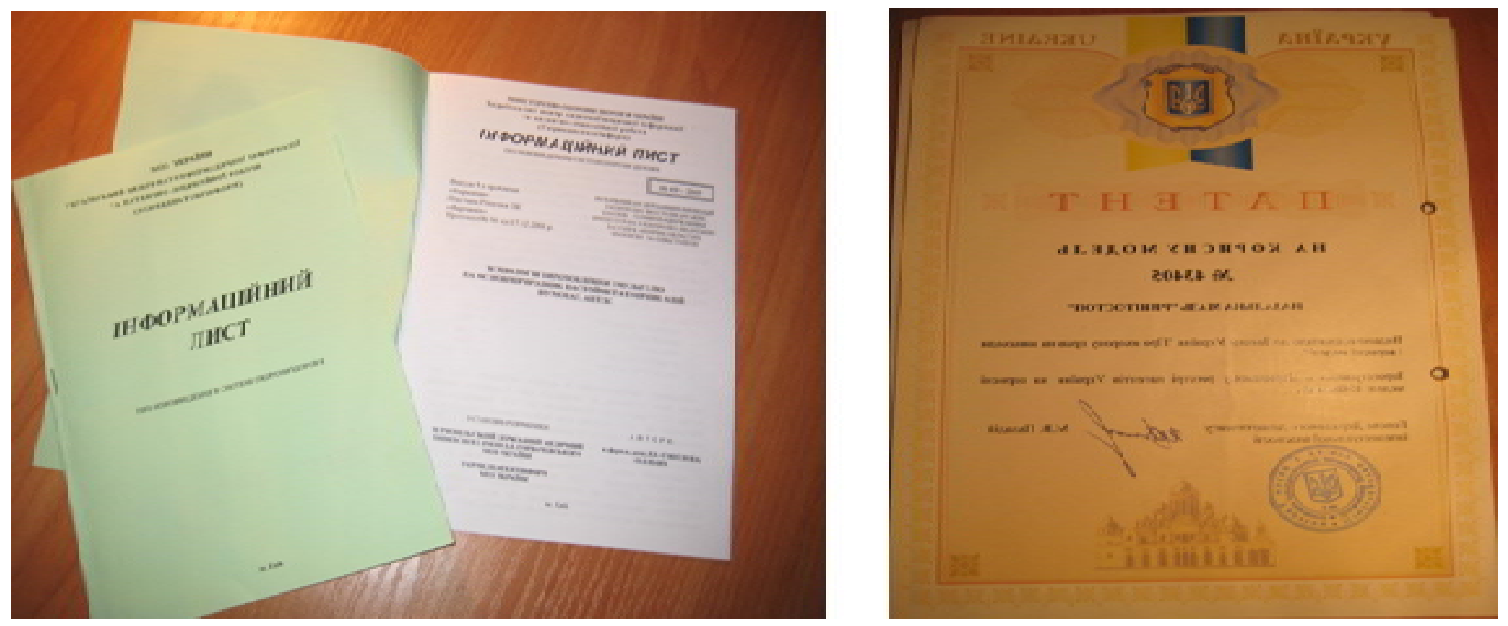

- Заохочувати магістрів за спеціальностями “Фармація" та "Клінічна фармація" до продовження експериментальних досліджень, що дозволить здійсню-

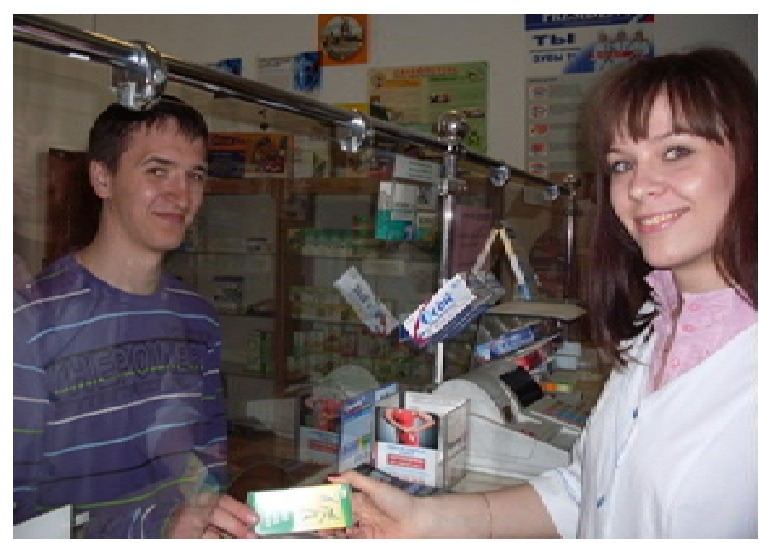

· Поглиблювати співпрацю з провідними вітчизняними та закордонними науково-дослідними установами з метою забезпечення підготовки фахівців у галузі фармації відповідно до світових вимог та тенденцій.

- Систематично контролювати хід виконання дисертаційних робіт. Створювати необхідні умови для ïx своєчасного виконання. Клопотати перед ректоратом про матеріальне заохочення осіб, які захистилися, та наукових керівників і консультантів.

Викладачі і студенти факультету активно співпрацюють 3 іншими навчальними закладами і фармацевтичною спільнотою. Традиційним стало проходження практики нашими студентами в східних областях України, зокрема з контролю якості лікарських засобів на базі Запорізького державного медичного університету, практики з технології косметичних засобів на фабриці “Ефект” та у Національному фармацевтичному університеті (м. Харків). В свою чергу, студенти фармацевтичного факультету беруть участь у програмі обміну студентів і проходять прак- вати підготовку науково-педагогічних працівників для університету.

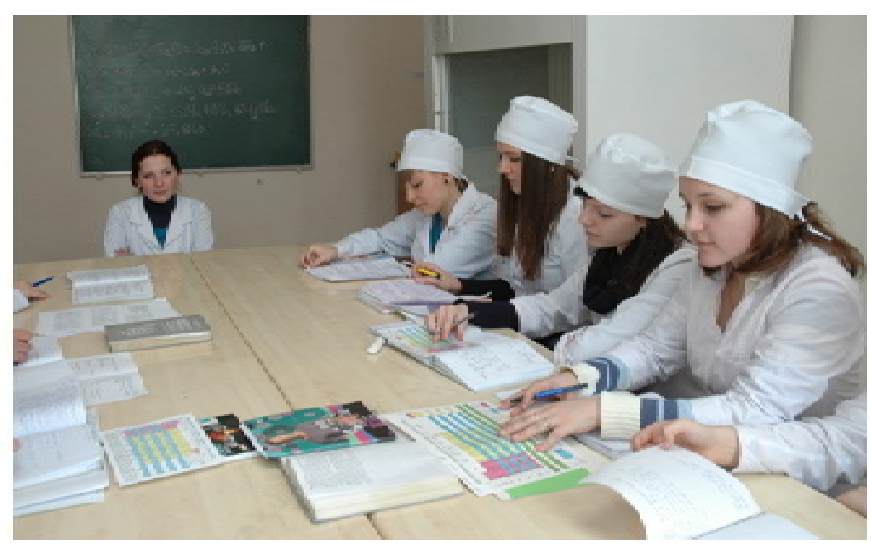

тику в аптечних закладах м. Вроцлава (Польша), а також стажування студентів з технології лікарських і косметичних засобів на заводі “Доктора Тайса" (Німеччина), що пізніше знайшло відображення в дипломних роботах, які були успішно захищені вищеназваними випускниками при проведенні їх державної атестації.

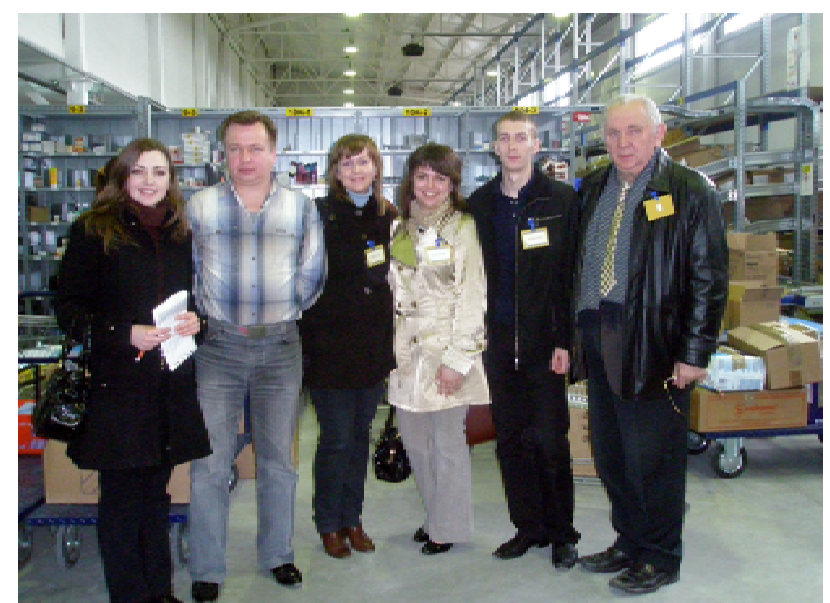


Майбутній фахівець 3 фармації має бути високоосвіченою, ерудованої особистістю з високими моральними принципами. Тому велику увагу необхідно приділяти виховній роботі. Для цього необхідно виховувати у студентів почуття гордості за свою Alma mater, свій факультет, що має базуватися на вагомих здобутках університету, факультету, рівні ерудиції викладачів факультету. Для цього:

- Організовувати силами викладачів і студентів щорічні святкові заходи до Дня фармацевтичного працівника, виховуючи повагу до своєї професії.

Продовжувати розвиток співдружності фармацевтичного факультету з іншими вітчизняними і закордонними навчальними закладами та фармацевтичною спільнотою.

· Популяризувати через засоби масової інформації здобутки фармацевтичного факультету.

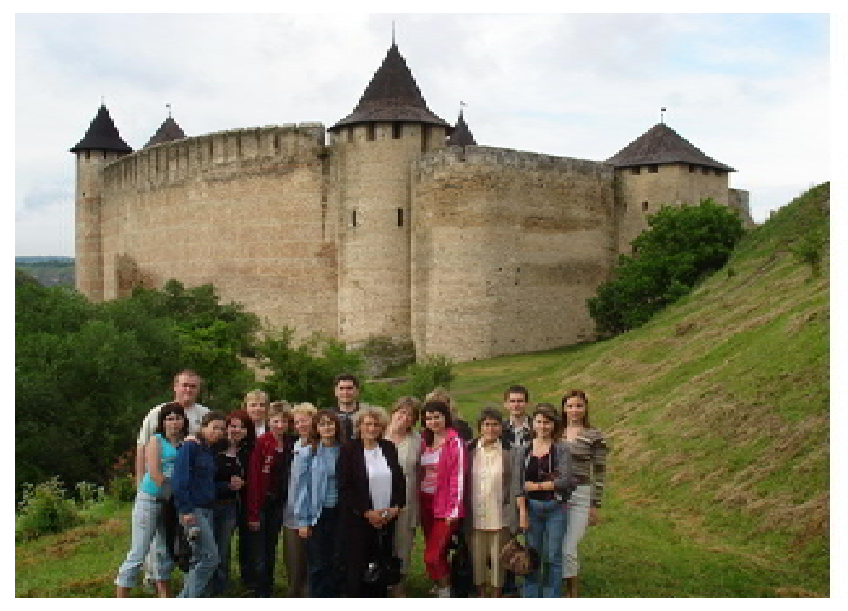

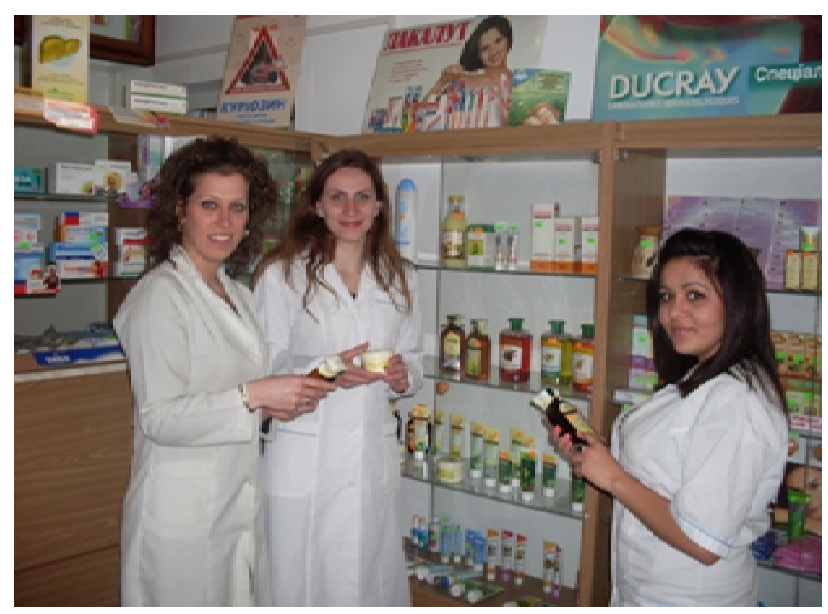

· Організовувати силами викладачів і студентів театралізовані свята Маланки, українські вечорниці, тематичні вечори тощо. Організовувати різнопланові екскурсії для студентів, викладачів.

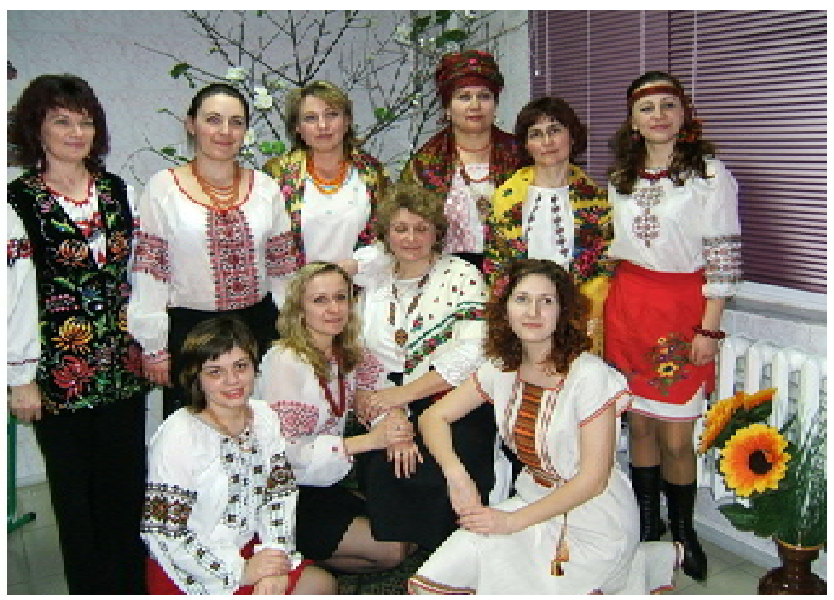

